\title{
Cywilizacja medialna a praktyka medyczna
}

Prof. DR hAB. MED. TOMASZ TROJANOWSKI

Uniwersytet Medyczny w Lublinie

Relacje pomiędzy chorym a lekarzem, a szerzej między społeczeństwem a światem medycznym odgrywają zasadniczą rolę w kształtowaniu poczucia bezpieczeństwa zdrowotnego zarówno w wymiarze indywidualnym, jak i zbiorowym oraz posiadają udokumentowany wpływ na wyniki leczenia.

Od starożytności zawód lekarza zaliczany był do profesji, szczególnej kategorii specjalności wymagających długotrwałego kształcenia, stażu i szczególnej odpowiedzialności za jakość działalności zawodowej. Osoby wykonujące takie zawody, uznawane za zawody zaufania społecznego, łączyły się w korporacje, ugrupowania zawodowe, cechy, zwane też gildiami, które dbały o wysoki poziom wykonywanych usług i świadczeń. Korporacje były dla społeczeństwa gwarantem usług na najwyższym poziomie. Powszechnie uznawano, że członkowie cechów najlepiej potrafią ocenić działalność swoich członków, posiadają bowiem do tego odpowiednia wiedzę i doświadczenie, zwykle niedostępne dla osób spoza profesji. W trosce o utrzymanie wysokiego 
prestiżu i zaufania społecznego zrzeszenia zawodowe tworzyły własne kodeksy etyczne, dbały, by dostęp do zawodu pozostawał pod ścisłą kontrolą. Posiadały też delegację środowiska do podejmowania działań dyscyplinujących członków niepodporządkowujących się ustanowionym zasadom. Korporacje ustalały zasady wykonywania zawodu, tworzyły system podnoszenia kwalifikacji zawodowych, stały na straży przestrzegania zasad etyki i godności zawodowej. Zapewniało to wysoki standard usług oraz utrwalało zaufanie do firmowanych przez cech produktów.

Wolne zawody wymienione były już w babilońskim Kodeksie Hammurabiego z 1772 roku p.n.e. Zaliczano do nich zawody: sędziego, bankowca, kapłana, lekarza, weterynarza, architekta.

Hipokrates (460-370 r. p.n.e.) uznawany za ojca współczesnej medycyny europejskiej, opisując zawód lekarza, używał sformułowań typowych dla regulacji zawodów cechowych. Wiele z tych poglądów i myśli Hipokratesa przetrwało i obowiązuje do dzisiaj.

Nie ulega wątpliwości, że od starożytności uznawano autorytet lekarza w zakresie medycyny, ale także jako elity intelektualnej i moralnej społeczeństwa. Z czasem stopień zaufania do lekarzy ulegał zmniejszeniu. Zjawisko to ma wiele przyczyn. Poszerzanie wiedzy medycznej, specjalizacja stopniowo prowadziły do powstawania w środowisku lekarskim zróżnicowanych możliwości leczenia, stosowania odmiennych metod oraz wyłaniania się budzących dyskusje poglądów na temat sposobów leczenia. Pacjenci mogli 
odczuwać niepewność, czy proponowany sposób leczenia i postępowania jest w ich przypadku najlepszy z możliwych. W wielu systemach politycznych pojawiały się poglądy, że państwo i stanowione prawo powinny gwarantować wysoką jakość i bezpieczeństwo w obszarze leczenia. W związku z tym wprowadzano coraz szerzej przepisy regulujące wszelkie aspekty działalności lekarskiej. Przepisy te ingerowały w system samokontroli samorządu i towarzystw lekarskich, a nawet je całkowicie zastępowały. Pojawiła się krytyka solidarności zawodowej, oskarżana o skrywanie przed otoczeniem nieprawidłowości we własnym gronie. Nawet jeżeli na poparcie tych opinii znajdowano przykłady, to na pewno nie wskazywały one na powszechność zjawiska. Zastępowanie dotychczasowej działalności regulacyjnej i kontrolnej korporacji lekarskich regułami prawnymi obniżało ich rangę i stopniowo pozbawiało zaufania pacjentów do lekarzy.

Praktyka pokazuje, że wysoce złożonej, szybko zmieniającej się wraz z postępem cywilizacji praktyki medycznej nie można skutecznie regulować administracyjnie i w ten sposób zagwarantować chorym możliwie najlepsze leczenie.

Zastępowanie osobistych, nacechowanym wzajemnym zaufaniem i wspólnotą celów relacji między chorym a leczącym go lekarzem wysoce sformalizowaną relacją wynikającą z przepisów istotnie zmieniło praktykę lekarską, przyniosło wiele szkód i staje się coraz częściej przedmiotem krytyki. Znaczny wpływ na omawiane zmiany miał 
ogromny rozwój i rozpowszechnienie środków komunikacji medialnej. Wiedzę o świecie obecne społeczeństwa czerpią z różnorodnych środków przekazu, prasy, radia, telewizji, a ostatnio Internetu. Obserwowane jest zjawisko podważania tradycyjnych autorytetów, a w zalewie wiadomości trudno ocenić wartość poszczególnych z nich.

Obecny etap rozwoju nazywany jest popularnie cywilizacją medialną. Opiera się ona na społeczeństwie informacyjnym, które cechuje wszechobecność mediów, które są głównym narzędziem komunikowania się jednostek.

Od dawna o rozwoju społeczeństw w znacznej mierze decydowała zdolność do wyrażania i przekazywania myśli innym członkom społeczności. Dzięki temu z doświadczeń jednostek mogą korzystać wszyscy członkowie społeczeństwa, a kolejne pokolenia - $\mathrm{z}$ doświadczeń i dorobku pokoleń poprzednich. Naturalnym środkiem komunikowania się jest mowa i gesty (mowa ciała). Są one nietrwałe i mają ograniczony zasięg, stąd wielki wpływ na rozwój cywilizacji miał rozwój trwałych metod komunikacji w postaci pisma, druku, łączności elektronicznej o praktycznie nieograniczonym zasięgu. Wielka, rewolucyjna zmiana w dostępności do informacji i przekazu myśli, której jesteśmy uczestnikami, ma doniosły wpływ na stosunki społeczne, co znakomicie można prześledzić, obserwując zmiany w relacjach pomiędzy chorym a lekarzem ${ }^{1}$.

1 T. Goban-Klas, Cywilizacja medialna. Geneza, ewolucja, eksplozja, Warszawa 2005. 
Jeszcze kilkanaście lat temu w relacjach chory-lekarz dość powszechne było całkowite wzajemne zaufanie. Chory zgłaszał się do lekarza w razie choroby czy dolegliwości $\mathrm{z}$ niezachwianym przekonaniem, że ten udzieli mu możliwie najlepszej porady i zapewni leczenie. Uważano, że ugruntowany od lat autorytet $i$ wysokie standardy etyczne lekarza stanowią tego gwarancję. Zwykle chorzy oczekiwali jedynie ogólnego przedstawienia problemu medycznego, rozpoznania, rokowania, wskazania możliwości leczenia i oceny jego skuteczności. Nie wnikali w szczegóły sposobu przeprowadzenia zabiegów medycznych, mechanizmów choroby, budowy aparatury i narzędzi używanych w czasie operacji. Uważano, że stanowi to domenę lekarzy i można z pełnym zaufaniem poddać się leczeniu przez nich proponowanemu. Zaufanie stanowiło fundament relacji. Taka postawa panowała przez wiele stuleci. Już Hipokrates pisał, że lekarz powinien podejmować za pacjenta jedynie słuszne decyzje w zakresie rozpoznawania i leczenia choroby. Podejmując leczenie, czyni to dla dobra chorego, ale może przy tym pomijać lub ograniczać jego autonomię, a przy tym podważać partnerstwo i świadomy udział chorego w leczeniu.

Ten typ relacji został określony jako paternalizm, rozumiany jako stosunki zbliżone do zasad rządzących życiem rodziny podporządkowanej władzy ojca. Paternalizm upoważniał do wpływania, a nawet wymuszania postępowania osoby lub grupy, co było motywowane ich dobrem. Zakładał niezdolność do samodzielnego, właściwego kierowania 
swoim postępowaniem. Zjawisko paternalizmu występowało w stosunkach rodzinnych, edukacji, polityce, medycynie ${ }^{2}$.

W latach siedemdziesiątych ubiegłego wieku idea paternalizmu w medycynie została poddana ostrej krytyce głównie w kręgach bioetyków anglo-amerykańskich. Wskazywano, że narusza ona autonomię chorego. Sporu pomiędzy zwolennikami a przeciwnikami paternalizmu nie udało się rozstrzygnąć nawet w oparciu o cztery zasady bioetyki, czyli autonomię, nieszkodzenie, dobroczynność i sprawiedliwość. Zasady te zostały sformułowane przez Toma L. Beauchampa i Jamesa F. Childressa. Brak precyzyjnego zdefiniowania poszczególnych zasad prowadzi do konfliktu pomiędzy autonomią pacjenta a autonomią i dobroczynnością lekarza³.

Zasadne jest uznanie, że lekarz w oparciu o posiadaną wiedzę i kierując się utrwalonymi zasadami zawodowymi, działa w najlepszej wierze dla dobra chorego. Kwestia paternalizmu związana jest z niezbyt wyraźnie podkreślanym problemem różnic w wartościach życiowych wyznawanych przez obie strony. Dla muzyka zachowanie słuchu

2 T. Biesaga, Autonomia lekarza i pacjenta a cel medyczny, „Medycyna Praktyczna" nr 6 (2005); K. Wroński i in., Opinie pacjentów na temat modelu paternalistycznego w relacji lekarz-pacjent. Prawne aspekty autonomii pacjenta w opiece zdrowotnej, „Nowotwory Journal of Oncology” vol. 59 (2009), no. 4 .

3 T.L. Beauchamp, J.F. Childress, Principles of Biomedical Ethics, 5th edn., Oxford 2001. 
może być ważniejsze niż zachowanie wzroku, jeżeli choroba wymusza poświęcenie jednego $\mathrm{z}$ nich dla ratowania życia. Dlatego lekarzy obowiązuje dobre poznanie systemu wartości uznawanych przez chorego i ustalenie wagi związanych z chorobą i leczeniem potencjalnych zaburzeń funkcji. W tym zakresie napotykamy często zaskakujące opinie. Ostatnio w publicystyce medycznej przetoczyła się dyskusja nad wartościami leczenia wrodzonej głuchoty, którą można obecnie usunąć, wszczepiając protezy elektroniczne. Środowisko osób niesłyszących uważa, że głuchota może być wartością pozwalającą cieszyć się udziałem w społeczności językowej i kulturowej osób niesłyszących. Językoznawca, profesor Marek Świdziński przekonuje, że "głuchy to nie kaleka, tylko cudzoziemiec. Próba przywrócenia słuchu ma taki sens jak leczenie cudzoziemca z cudzoziemskości”.

Respektowanie udziału chorego w podejmowaniu świadomych decyzji o leczeniu jest obecnie powszechne i lekarze wykazują dużo pokory i szacunku dla poglądów i przekonań leczonych pacjentów ${ }^{4}$.

Krytyka idei paternalizmu wynikała w dużej mierze ze zmian politycznych i społecznych nieakceptujących jej w dziedzinie makroekonmii, gdzie paternalizm uzasadniał szerokie ingerowanie państwa w rynek dla ochrony

4 H. Lane, M. Grodin, Ethical Issues in Cochlear Implant surgery: An Exploration into Disease, Disability, and the Best Interests of the Child, „Kennedy Institute of Ethics Journal" 7.3 (1997), s. 231. 
jednostek, a w skali międzynarodowej polegał na opiekuńczej roli krajów kolonialnych nad krajami o niższym stopniu rozwoju gospodarczego i społecznego. Zatem był kojarzony z hierarchicznymi stosunkami rodzinnymi i społecznymi, w tym kolonialną dominacją jednych państw nad innymis.

Położenie ogromnego nacisku na podmiotowość chorego, szeroka ingerencja polityki i administracji w organizację i wykonywanie zawodu lekarza stanowią podłoże zasadniczych zmian w relacjach chory-lekarz. Politycy deklarują, że w trosce o dobro społeczeństwa zapewniają wszystkim obywatelom bezpieczeństwo zdrowotne i leczenie w razie potrzeby, często nie zapewniając wystarczających środków i struktur organizacyjnych. Mnożone są administracyjne mechanizmy kontroli działalności medycznej, szczególnie gdy finansowana jest ona ze środków publicznych. Media chętnie ogłaszają sukcesy medycyny i jej postępy, często stwarzając wrażenie, że osiągnięcia badawcze i laboratoryjne zostaną natychmiast $\mathrm{z}$ powodzeniem przeniesione do praktyki codziennej, co niestety zdarza się wyjątkowo rzadko. Kodeksy etyki lekarskiej kategorycznie zakazują ogłaszania w publicznych mediach wyników badań stwarzających nadzieję chorym na rozwiązanie ich trudnych problemów zdrowotnych, zanim wyniki te nie zostaną opublikowane w czasopismach naukowych, gdzie mogą

5 G. Dworkin, The Theory and Practice of Autonomy, New York 1988; M. Gulczyński, Panorama systemów politycznych świata, Warszawa 2004. 
być poddane fachowej ocenie. Konkurencja i pokusa sławy czasami stanowią przyczynę łamania tej zasady.

W społeczeństwie panuje przekonanie, że istnieją możliwości wyleczenia praktycznie każdej choroby, a za niepowodzenia obwiniają lekarzy, przypisując im zaniechania, nieudolność lub niewiedzę. W takiej sytuacji chorzy i ich bliscy sięgają czasami do narzędzi prawnych, żądając zadośćuczynienia za brak wyleczenia. Relacja chorego z lekarzem w świadomości pacjenta coraz częściej przypomina kontrakt na zakup przedmiotu z gwarancją. Przedmiotem $\mathrm{w}$ rozumieniu chorych jest zdrowie, które można nabyć za określoną kwotę, a wady „nabytego produktu” muszą być naprawione w ramach gwarancji. Niestety lekarze nadal nie mają zdrowia na sprzedaż, mogą jedynie oferować leczenie, a wobec ogromnej złożoności świata przyrody może się ono okazać niezadowalające lub wręcz nieskuteczne. Medycyna nadal nie jest wszechwładna, nie dysponuje metodami pozwalającymi na skuteczne wyleczenie wielu chorób, chociaż postęp w tej dziedzinie jest niewątpliwie imponujący.

Media, obok przejaskrawionych sukcesów, osiągnięć i możliwości medycyny, chętnie eksponują nieprawidłowości i nieszczęścia w przebiegu leczenia i opieki nad chorymi. Chociaż niewątpliwie takie zjawiska mają miejsce i są godne napiętnowania, stanowią one margines działalności lekarskiej. Z przeglądu doniesień medialnych można jednak odnieść wrażenie, że błędy, brak wiedzy i zaniedbania są powszechne i wymagają coraz szerszej ingerencji prawa 
i regulacji administracyjnych w działalność tej grupy zawodowej. Opisy przypadków błędów medycznych, korupcji i zaniechań często zdobią okładki czasopism i są tematem popularnych programów telewizyjnych. Korporacje medyczne mają bardzo ograniczony wpływ na przedstawiane treści, chociażby w formie ukazania obiektywnych ocen czy stanowiska oskarżanych lekarzy i instytucji medycznych. Sprzyja to publikowaniu i rozpowszechnianiu pochopnych, nieobiektywnych, zwykle emocjonalnych interpretacji wydarzeń. Stanowi to jedną z ważnych przyczyn zrywania więzi nacechowanych zaufaniem między chorym a lekarzem.

Prymat ochrony podmiotowości pacjenta zmienił prawo do udziału rodziny i najbliższych chorego w podejmowaniu decyzji w zakresie leczenia. Jeżeli chory nie wskaże konkretnej osoby upoważnionej do uzyskiwania informacji o swoim stanie zdrowia i do dostępu do dokumentacji leczenia, a sam w wyniku choroby utraci zdolność wyrażania woli, kolejne działania medyczne mogą być przeprowadzane jedynie po uzyskaniu zgody sądu, a bliscy nie mają prawa uzyskać informacji o przebiegu leczenia. Wyjątek stanowią działania ratujące życie, przeprowadzane na podstawie decyzji komisji lekarskiej. Decyzje te muszą być następnie zgłaszane do sądu. Jest to jeden z przykładów braku zaufania do działań lekarzy dla dobra i w interesie chorego. Rodzina chorego nieprzytomnego trafiającego do szpitala nie ma formalnie prawa do informacji o jego stanie zdrowia, a sposób leczenia jest uzgadniany 
z sądem rodzinnym. Stanowi to przykład ograniczania zaufania wobec właściwych motywów poczynań lekarzy, przyświecających im zasad dobroczynności i autonomii, na rzecz autonomii chorego.

$\mathrm{Na}$ relacje pomiędzy chorymi a lekarzami w dużym stopniu wpływa powszechna dostępność Internetu, który stał się głównym źródłem wiedzy i opinii dla większości społeczeństwa, a także miejscem wyszukiwania rozwiązań problemów. Bardzo często pacjenci poszukują wyjaśnienia przyczyn dolegliwości w Internecie, próbują samodzielnie rozpoznawać choroby, znajdować sposoby ich leczenia, a także weryfikować zalecenia lekarzy. „Dr Google" stał się powszechnie używanym pojęciem. W rzeczywistości problemy medyczne są zwykle złożone i bez przygotowania, studiów i doświadczenia bardzo trudno w krótkim czasie, na podstawie ogromu niesklasyfikowanej pod względem merytorycznym i niezweryfikowanej informacji, postawić trafne rozpoznania i ustalić właściwe metody leczenia.

Innym powszechnym sposobem wykorzystywania Internetu i środków masowego przekazu jest wyszukiwanie najlepszych produktów na rynku, w tym najlepszych lekarzy. Znajduje to odbicie w obecnie używanych określeniach lekarza i chorego jako świadczeniodawcy i świadczeniobiorcy. Odpowiedzią na opisane zapotrzebowanie są okresowe rankingi szpitali, oddziałów poradni i lekarzy, a w Internecie istnieją stałe witryny zatytułowane „dobry lekarz”, „najlepszy lekarz”, „najlepszy ortopeda, chirurg, 
ginekolog”, „najlepsze leczenie otyłości, hemoroidów, bólów krzyża czy zmarszczek".

Portale zachęcają potencjalnych pacjentów do przejrzenia i zapoznania się z listami lekarzy oraz opiniami o nich, zanim dokonają wyboru.

Rankingi opierają się na niejasnych kryteriach oceny „jakości lekarza”, cokolwiek to by miało znaczyć. Jakości nie można oceniać tylko na podstawie opinii pacjentów, na które przemożny wpływ ma sposób bycia, powierzchowność i klimat kontaktów. Rzeczywistą wiedzę, umiejętności i sprawność w wykonywaniu zabiegów mogą oceniać pokrewni specjaliści, pewną pomocą może być też dobrze przygotowane omówienie wyników leczenia według obiektywnych kryteriów. Fora internetowe są pełne ocen lekarzy, opartych głównie na pierwszym wrażeniu osoby piszącej opinię. Widoczna jest też dominacja ocen negatywnych, bowiem wiadomo, że niezadowoleni mają większą skłonność do opisywania swoich doświadczeń niż osoby neutralnie lub pozytywnie oceniające przebieg swojego leczenia. Wyraźnie widoczne są zjawiska „mowy nienawiści” i aktywność „hejterow”. Wiarygodność ocen jest podważana przez istnienie szeregu mechanizmów umożliwiających wpływanie na kształt list popularności i ocen lekarzy. Wykorzystywane są one w wielu dziedzinach życia, komercji, reklamie i polityce. Istnieją portale, w których można umieścić swoje dossier na pozycji zależnej od wpłacanej ceny, a także zapewnić sobie korzystne opinie i usuwanie niepochlebnych. 
Internet wykorzystywany jest także do promowania lecznic czy metod leczenia. Czasami informacje publikowane na stronach internetowych wprowadzają w błąd opinię publiczną, bo są redagowane $z$ uwzględnieniem chwytów marketingowych. W ogłoszeniach o nowościach medycznych stosowane jest nazewnictwo rodem z reklamy. Przykładem może być informacja, że dr X wprowadził na salę operacyjną „technologię z gwiezdnych wojen”, w rzeczywistości polegającą na użyciu kamery termowizyjnej do oceny postępu w usuwaniu naczyniaka. Jest to metoda o niepotwierdzonej wartości, ale miała pozwolić stosującemu ją lekarzowi na osiąganie wyników „o lata świetlne lepszych niż zwykle".

Nazwanie ekranu plazmowego monitora na ścianie sali operacyjnej „RGB Spectrum's SuperView Video Processor" pozwala na użycie sloganu o pionierskiej technologii w chirurgii.

Ponieważ szybko postępuje komercjalizacja medycyny, nasila się zjawisko konkurowania o pacjenta, które sprzyja obniżaniu standardów etycznych.

Klimat ograniczonego zaufania do lekarzy sprawia, że coraz więcej przypadków niepowodzenia leczenia $w$ ocenie chorych traktowanych jest jako błędy lub zaniechania i opinie te rozstrzygane są w sądach. Stwarza to i nasila zagrożenie instytucji medycznych i lekarzy kosztownymi procesami i odszkodowaniami. Wzrastają systematycznie opłaty za ubezpieczenia od odpowiedzialności cywilnej. W pewnych okresach powodowało to masowe odchodzenie 
lekarzy od uprawiania niektórych specjalności, obarczonych wysokim ryzykiem powikłań i niepowodzeń. W takiej sytuacji znalazł się przed laty rząd Margaret Thatcher, który dla ratowania sytuacji przejął koszty ubezpieczenia położników i anestezjologów.

Zagrożenie oskarżeniami i procesami stworzyło medycynę obronną (defensive medicine). Polega ono na zlecaniu licznych badań i zabiegów, niekoniecznych z punktu widzenia procesu leczenia, ale służących zabezpieczeniu się leczących przed zarzutami braku staranności, niewykorzystania wszystkich możliwości diagnostycznych i leczniczych czy braku wystarczającej staranności. Naraża to chorych na niepotrzebne procedury i potencjalne powikłania, a także znacznie podnosi koszty leczenia. Liczne procesy powodują, że lekarze coraz więcej czasu poświęcają na pisanie wyjaśnień i udział w postępowaniach sądowych.

Niepokojącym zjawiskiem wynikającym z zagrożenia procesami jest unikanie przez lekarzy podejmowania zabiegów o wysokim ryzyku powikłań i niepowodzeń, pomimo że mogą one stanowić jedyny sposób na poprawę losu chorego. Zjawisko to zostało przedstawione m.in. w programie Neurosurgeons 'fear risky surgery' (BBC, 15 czerwca 2000, 22:05 GMT). Wykazano w nim, że niektórzy neurochirurdzy unikają skomplikowanych operacji z powodu obaw przed skutkami prawnymi i finansowymi w przypadku ich niepowodzenia. Zjawisko to ma szersze znaczenie, bowiem część postępu w medycynie zawdzięczamy podejmowaniu leczenia o wysokim stopniu ryzyka, 
ale przynoszącego korzyści chorym i po udoskonaleniu wchodzącego do powszechnego arsenału terapeutycznego.

Obserwowane jest zjawisko wybierania „bezpiecznych" specjalizacji przez adeptów studiów medycznych, co w przyszłości ograniczy dostępność do leczenia w dziedzinach „niebezpiecznych”.

Zmieniające się uwarunkowania prawne prowadzą do możliwości uzyskania odszkodowań z tytułu złego urodzenia (wrongful birth). Dziecko urodzone $z$ wadami wrodzonymi i jego rodzice mogą żądać odszkodowań od lekarzy prowadzących doradztwo genetyczne za niewłaściwą ocenę ryzyka poczęcia dziecka $\mathrm{z}$ wadami uwarunkowanymi genetycznie albo pozbawienie rodziców wiedzy o wadach płodu i możliwości podejmowania decyzji o aborcji. Pierwszy taki proces przed sądem apelacyjnym w New Jersey odbył się w 1967 roku (Gleitman v. Cosgrove), a w krajach europejskich w roku 1991 w Niemczech, w roku 1982 w Wielkiej Brytanii, we Francji w 1993 roku, a w Polsce w 2002 roku.

Lekarze mogą być uznani za winnych niedbałości przy nieskutecznym zabiegu sterylizacji w przypadku narodzenia niechcianego dziecka, co nosi nazwę „złe poczęcie” (wrongful conception).

Z kolei istotą powództwa z tytułu „złego życia” (wrongful life) jest roszczenie odszkodowawcze za cierpienie i kalectwo dziecka urodzonego z fizycznymi lub psychicznymi wadami skierowane wobec lekarzy. W USA powództwo o odszkodowanie za życie w cierpieniu może być skierowane także przeciwko własnym rodzicom. 
Bardzo niepokojącym zjawiskiem związanym z komercjalizacją medycyny jest wykonywanie szczególnie wysoko wycenionego leczenia i zabiegów bez wystarczających wskazań medycznych. Zjawisko to obserwowane jest $\mathrm{w}$ wielu krajach na świecie. Jeden $\mathrm{z}$ raportów $\mathrm{z}$ USA na podstawie analiz statystycznych i publikacji wskazuje, że liczba zbędnie ordynowanych antybiotyków w zakażeniach wirusowych przekracza $20 \mathrm{mln}$ rocznie, a liczba zbędnych medycznych i chirurgicznych procedur $7,5 \mathrm{mln}$ rocznie. Wykazano, że 8,9 mln pacjentów było zbędnie przyjętych do szpitala. Do najczęściej wykonywanych zabiegów z wątpliwymi wskazaniami medycznymi należą zabiegi na naczyniach wieńcowych, usunięcie macicy, cięcie cesarskie, operacje kręgosłupa ${ }^{6}$.

Zjawiska związane z medycyną obronną, problemami prawnymi i niekonieczną kwalifikacją do leczenia znacznie podnoszą koszty leczenia. Według danych PriceWaterhouseCoopers Health Research Institute (2008) na straty w ochronie zdrowia osiągające w USA 1,2 mld USD rocznie składa się: nadmiar badań - $210 \mathrm{mld}$, procesy

6 Death by Medicine By Gary Null, PhD; Carolyn Dean, MD, ND; Martin Feldman, MD; Debora Rasio, MD; and Dorothy Smith, PhD, [on-line:] http://www.webdc.com/pdfs/deathbymedicine.pdf [dostęp: 6.11.2016]; Avoid Unnecessary Procedures and Medical Errors. An interview with Rosemary Gibson, co-author of „The Treatment Trap. Tom Lombardo”, „AARP Bulletin", 8.04.2010; S. Scott, Unnecessary antibiotics, medical tests, procedures may harm patients. NPS MedicineWise, [on-line:] http://www.abc.net. $\mathrm{au} /$ news/2016-03-16/unnecessary-medical-tests-and-treatments-may-harm-patients/7248234 [dostęp: 16.03.2016]. 
i odszkodowania - $210 \mathrm{mld}$, nieprzestrzeganie zaleceń lekarskich - 100 mld, nieskuteczne wykorzystanie technologii medycznych - $88 \mathrm{mld}$.

Zadaniem dla świata lekarskiego mającym na celu przywrócenie relacji między chorymi a lekarzami, opartej na wzajemnym zaufaniu, jest podjęcie działań, by chorzy mogli całkowicie ufać lekarzom, by lekarz i system ochrony zdrowia był „opiekunem spolegliwym”. Według Tadeusza Kotarbińskiego, filozofa i wielkiego etyka „opiekun wtedy jest spolegliwy, kiedy można słusznie zaufać jego opiece, że nie zawiedzie"8.

7 P. B. Kavilanz, Health Care's Six Money-Wasting Problems, [on-line:] http://money.cnn.com/2009/o8/10/news/economy/healthcare_money_ wasters/ [dostęp: 6.11.2016]; US Health Care System „Wasted” $\$ 750$ Billion in 2009, [on-line:] http://abcnews.go.com/blogs/health/2012/og/o6/us-health-care-system-wasted-75o-billion-in-2009/ [dostęp: 6.11.2016].

8 T. Kotarbiński, Pisma etyczne, Wrocław 1987, s. 520. 